\title{
On the Relation of Carbohydrate Metabolism in Pancreatectomized Diabetic Dog and Alloxan Diabetic Dog
}

\author{
By
}

\section{Tadamasa FuJITA}

Department of Internal Medicine, 2 Division Kobe Medical College (Prof. M. Takeda, Chief)

In order to compare the pancreatectomized dog with alloxan affected on the nature of the disordered carbohydrate metabolism, the author compared these two groups of animals on the presence or absence of a) the essential diabetic metabolic disorders and b) influences from extrapancreatic origins.

The methods adopted for the former were, 1) carbohydrate tolerance test, 2) test for the ability of sugar formation and 3) test for ketosis, and for the latter, test for insulin sensitivity of biood sugar.

\section{Results obtained :}

1) The ioss in the glucose tolerance was less severe in the alloxan dog than in the totally pancreatectomized; however, was severer in the former than in the 9/10 depancreatized dog. As to disagreement of the blood sugar regulating function, generally in the alloxan dog, the negative Staub-Effect was not so markedly present comparatively for the rise of blood sugar curve.

2) With regard to the ability of sugar formation, the fasting blood sugar levels and daily whole urine sugar contents were determined with the following results.

In general, in the alloxan dogs, the blood sugar levels were lower than those of the totally or partially depancreatized dogs. In severer cases, in the pancreatectomized dogs the blood sugar rose before death, but in the alloxan dogs it dropped gradually.

The urine sugar excretion was of special character, and in the alloxan dogs it was markedly high, and from the initial stage, much urine sugar was exereted comparatively for the blood sugar level.

3) On the grade of ketosis in both kinds of dogs, it was relatively variable in each case, and generally in the alloxan dog, the values of blood and urine ketone bodies were higher than those of the pancreatectomized dog.

4) With the insulin sensitivity of blood sugar careful observations revealed marked differences between the two groups.

a) The insulin sensitivity in the alloxan dog was rather remarkably higher than that of in the pancreatectomized — the mean maximal drop in the pancreatectomized dog being $55.5 \%$ (roughly the normal range), while the alloxan dog showed $78.5 \%$.

b) In the alloxan dog, its attitude to insulin, i.e. the maximal rate of decrease (insulin effect), and the rate of increasing from the lowest to the final level (antiinsulin effect), was constant almost through the whole course, but in the pancreatectomized dog, both effects seemed to have remarkable variation by the days passed atter the operation.

c) In the pancreatectomized dog, the antiinsulin effect was low in the initial three weeks after the operation, but after 30 days or so, insulin and antiinsulin effects rose promptly and the dog became insulin-resistant. In the later stage, the antiinsulin effect dropped markedly again.

d) In the pancreatectomized dog, the cause of such remarkable changes in the insulin and anti-

$$
\text { Vol. } 31 \text { No, } 1
$$


insulin effects seem to relate closely with the sudden loss of $\alpha$-cell function in Langerhans' islets in the initial stage, and with rise and fall of the extra-pancreatic antiinsulin effect in the next stage.

5) In conclusion, the author comparing the pancreatectomized dog with the alloxan dog with respect to the carbohydrate metabolism, found that on the essential diabetic metabolic disagreement there existed somewhat marked differences on the ability of sugar formation and the sugar excretion into urine, but the insulin sensitivity of blood sugar showed remarkable differences between both kinds of dogs.

\title{
Experimental Studies on the Effects of Anterior Pituitary and Adrenal Cortical Hormones to the Blood Sugar and Diastase Volues of Normal and Alloxan Rabbits.
}

By

\section{Mizuto KAJIYAMA}

\author{
II. Division of Internal Medicine, Kobe Medical College (Director; Prof. M. Takeda)
}

Before and after injection of singie dose of ACTH, Cortisone or DCA into normal or alloxan diabetic rabbits, the auther determined the sugar and diastase values in the blood hour by hour for 6 hours. These determinations were done repeatedly 24 hours after injections. And the auther obtained following results;

1) In cases of normal rabbits, (a) the blood sugar values increased only after injection of Cortisone, and after injection of ACTH or DCA they intended to decrease in the beginning and then turn to approach to the values before injection. But after injection of large quantity of ACTH, the blood sugar values increased in the beginning and then decreased later. Among these 3 kinds of hormones, DCA and large quantity of ACTH showed larger blood sugar decreasing ability. (b) On the diastatic activities of the blood, they increased only after injection of large quantity of Cortisone, and after injection of Cortisone $(5 \mathrm{mg})$, ACTH or DCA they intended to decrease in the beginning and then turn to approach to the value before injection. On the other hand the blood diastase values decreased hour by hour until 6 hours after injection of large quantity of DCA. Among these hormones, $5 \mathrm{mg}$ Cortisone and $10 \mathrm{mg}$ DCA showed stronger blood diastase decreasing abilities. (c) In the respect of the relation between curves of blood sugar and diastase values, in cases of DCA or ACTH injections they were parallel in general, but in cases of Cortisone injections they showed nearly discrepancy each other.

2) In cases of alloxan diabetic rabbits after injections of these hormones, (a) the blood sugar values varied nearly identically with the cases of normal rabbits. Also in cases of alloxan rabbits, the blood sugar increased only after injection of Cortisone, and decreased significantly by ACTH or DCA. And among these hormones, DGA had the largest blood sugar decreasing power. (b) To the diastase values of the blood, ACTH showed the most remarkable changes, and after injection of it, the blood diastatic activities showed remarkable increase. On the other hand after injection of Cortisone or DCA the sugar and diastase values of the blood decreased. (c) Concerning to the relation between the curves of blood sugar and diastase values, they showed parallel after injection of DCA, and were discrepant each other by Cortisone or ACTH.

$$
\text { Vol, } 31 \text { No, } 1
$$




\section{除膵糖尿犬こ alloxan 糖尿犬こに 於ける糖質代謝上の比較} 神戶醫科大學第二內科學呚窒 (指導 竹田正次敉授) 藤田忠正

\section{第1章 緒言}

除膵糖尿病に關する實驗的研究はMering u. Minkowski (1889)やOpie (1901)以來多數に行われて居 るが，除膵によつては，膵炡「ラ」氏息 $\beta$ 細胞の內分泌閉止による諸種代謝失調以外に，脂肝が起事るを Allan(1924)によつて見出され, 其後抗胑肝性物質に關する研究から, 脂肝は「ラ」氏息 $\beta$ 細胞の內分泌作用

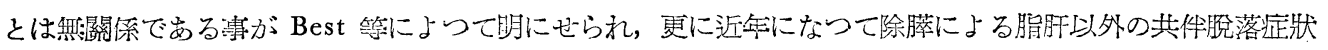
として,「ラ」氏島 $\boldsymbol{\alpha}$ 細胞の機刢が指摘せられる樣になつた.

それ故除膵動物に於ける諸種類の代謝失調像中には，「ラ」氏息 $\beta$ 細胞の內分必作用以外の代謝失調像も 共存して居る譯となる。

又他方 alloxan によつて, 動物に恒久性の糖尿病が起され得る事を Bailey a. Bailey(1943)pGoldner a. Gomori (1943) 等によつて見出されて以來, まだ其年月は新しいのに拘わらず, alloxan 糖尿の病因探 求に關する研究は極めて多數俩出した。

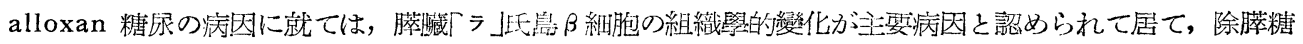

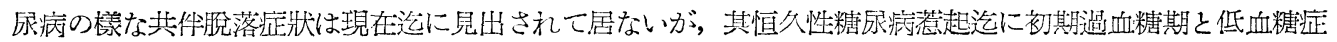

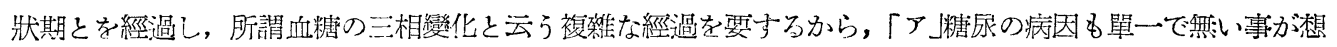

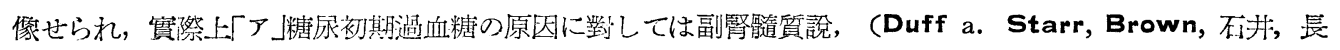

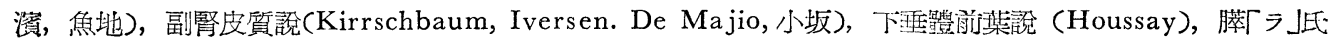

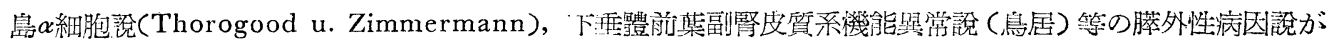
有力に主張せられて居る。



Houghes, Ware a. Young, Pausrjee, Dunn Sheehan a. Mc. Letchie, 岡本) 以外に副腎皮質說

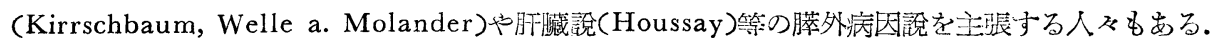

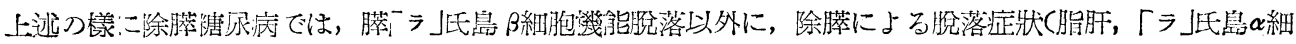

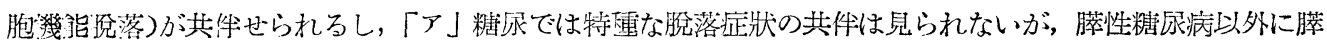
外性糖痕病共伴の可能性が多分に窥われる。

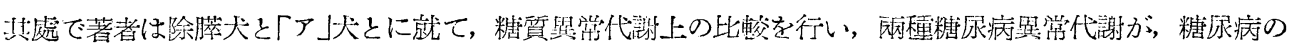
本質的代愔失調の基盤上では，幾何の相違を見られるかを比輍せん焦に，糖尿病の本質的代謝失調の代表的

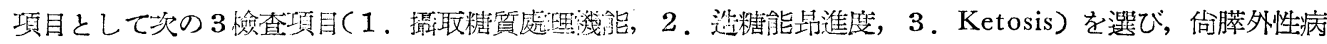

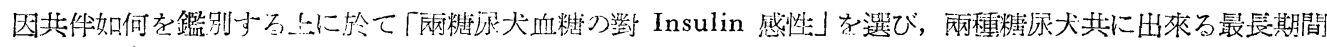
に亘つて生存せしめて，上記 4 项目に就て比輍索行つた。

\section{第 2 章 實驗材料並びに實驗方法}

\section{1）實驗動物}

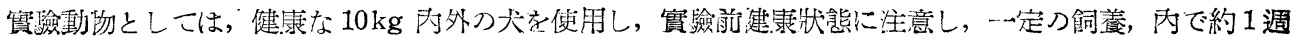
間適持つ運動をせしめつつ，一定つ食酙を以つて飼養した。 


\section{2) 除膵手術}

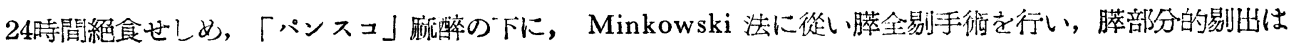
Allen 法に據り行い主膵管と連絡のある部分のみを殹めて僅かに殘した。

\section{3) allokan 糖尿犬}

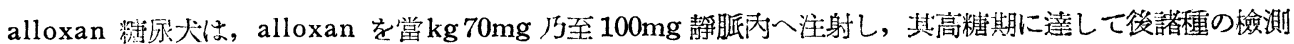
を行つた.

\section{4) 梌測方法}

a）血液及び尿「ヶトン體澌定は Behre の Salicylaldehyde 比色法を使用した。

b）血糖は Hagedorn 法, 尿糖は隈川, 須藤法に據つた。

c）糖處理機能憸查には，蕳萄糖二重傎荷試羷を行つた。

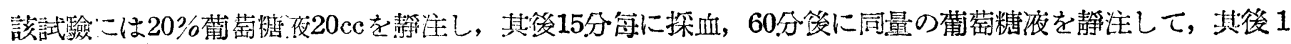
時閣に亘り15分荡に採血檢糖した。

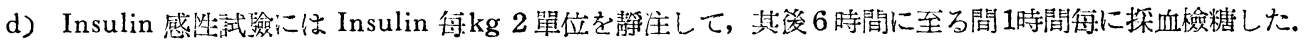

\section{第3章 實 驗 成 績}

\section{(I) 糖處理機能失調度比較}

既に本呚室では光永(昭和18年)が，除膵犬の糖二重負荷試臉を行つたが，其際は薄萄糖つ腹腔內注入法で むつた。著者は糖つ静注法を行つた。

（1）各種除膵犬に於ける糖二重負荷試驗

（a）膵全剔犬に於ける糖負荷試驗

今膵全剔犬の其手術前と術後 3 日目に於ける葡萄陏二重負熵試驗つ成績を示すと下の如くである。

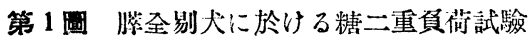

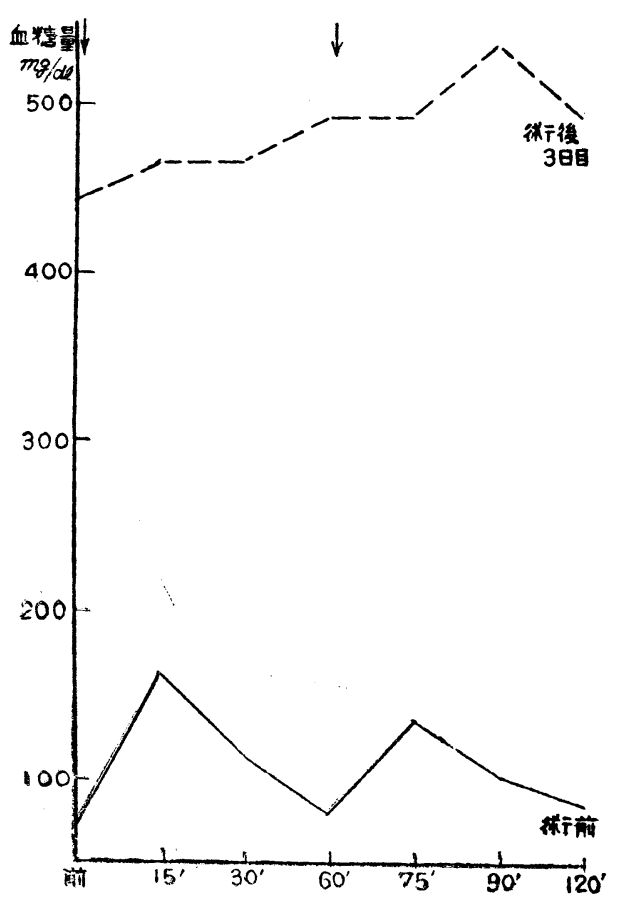

第 2 回

櫒星部剔犬に於ける糖二重頁荷試驗

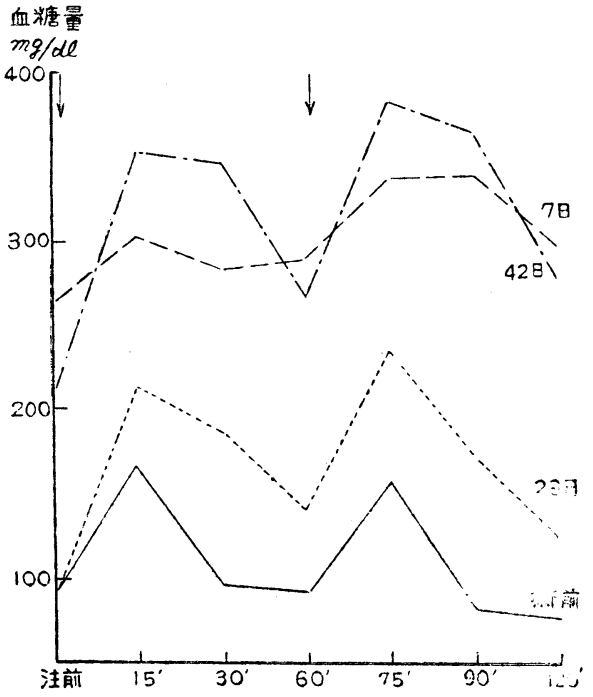




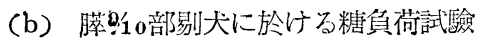

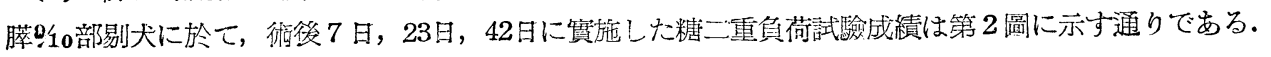

(c) 膵2 3 部剔犬に於ける糖真荷試驗

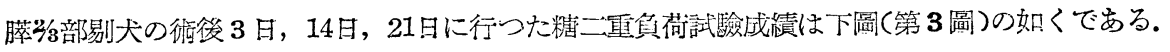

以上脺全剔，％10立びに \% 部剔犬に於ける術後の經過を追うて行つた糖二重負荷試騟成績を通覽して，其 糖處理機能失調度に對し，順位を附けると，勿論全剔夫に於ける糖處理機能失調度は最高度で，次は９１＼cjkstart部

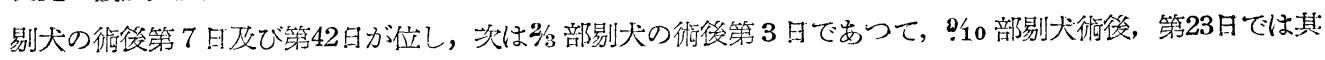

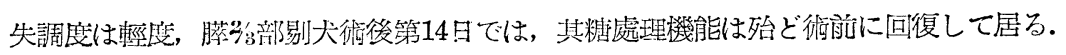

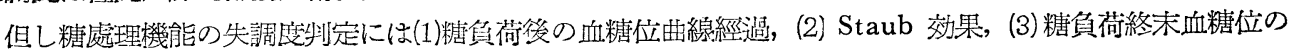
3 項目を其失調度制定の目標とした。

膵 90 部剔犬で術後第23日で, 其糖處理機能失調度がー一旦好轉したのに, 術後42日で再惡化を示したのは 如何なる原因かを該部剔犬に就て其血糖と尿糖の經遄(第3 表參照)を參照して見るのに, 該部剔犬では術後 第7日を頂點として，其後逐日早朝時血糖量は低下に向い，術後第I4日から第23日迄の間は早朝血糖量は殆

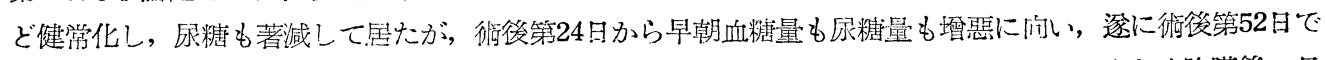
死亡した，其術後第23日迄は好淍回復を示し，其後漸次恶化に向つた原因は明でないが，恐らく除膵後一旦

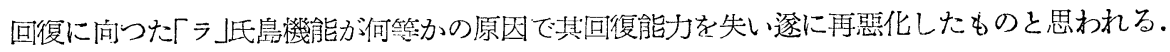

（2） alloxan 犬に於ける糖真荷試驗

「ア」(當 $\mathrm{kg} 100 \mathrm{mg}$ 瑇注) 糖尿犬に糖二重負蓷試驗を其經過に從つて數回行つた成績は第 4 圖に示す通り である.

「稘得爱第 3 日(I), 第 7 日(II), 第26日(II) に行つた糖負荷試羷の成績は大澧に於て相似である が，其糖處理機能失調度な刵定すれば（Ｉ）が最惡で (II)と(II)は略々同位である。

第 3 圑

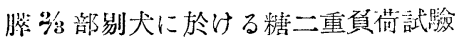

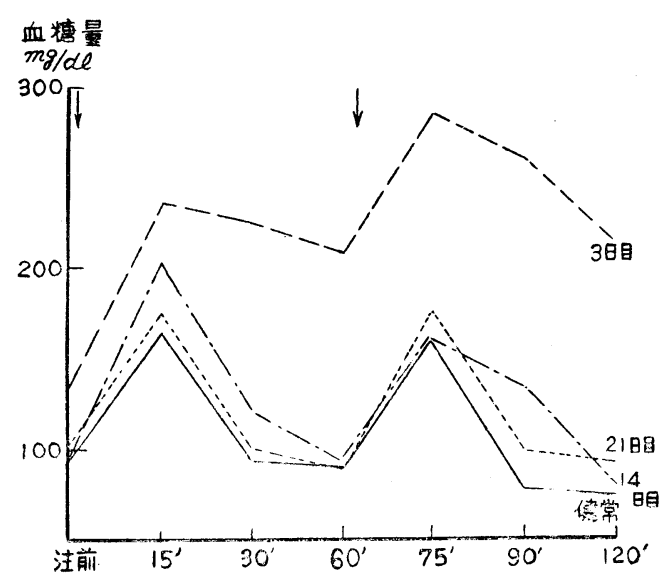

第 4 圖 Alloxan $100 \mathrm{mg} / \mathrm{kg}$ 貧荷糖 尿犬に於ける糖二重覔荷試驗

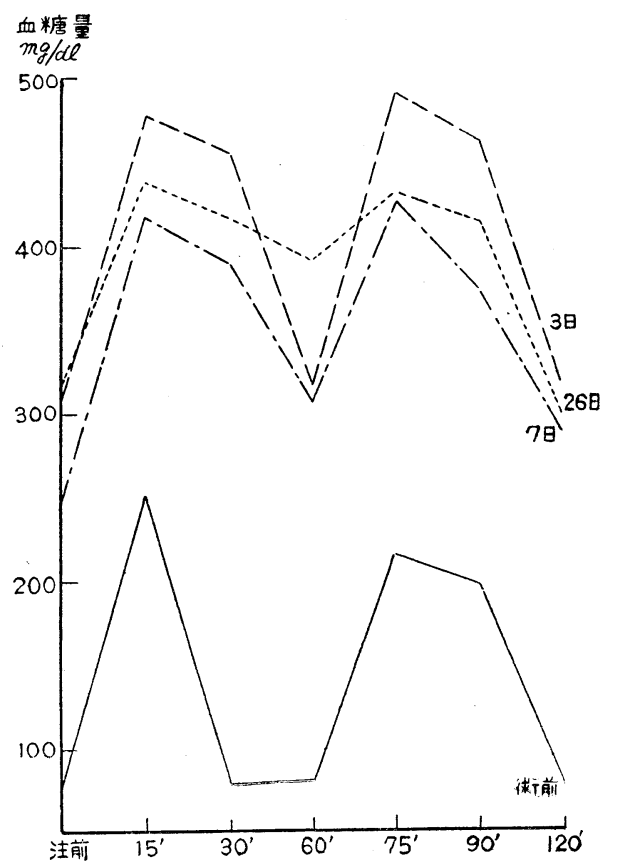

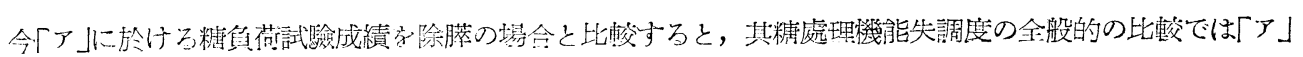

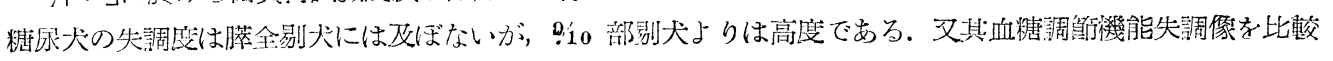


すると,一般に「ア」犬では其 全血糖位曲線經過の高位であ る割合に，Staub 效查の陰性 度が著明で舤い。

\section{(II) 造糖能昂進度比較}

今早朝時の高血糖に對䒚る 異常代謝過程の原因を考察寸 ると,

a. 肝に於け子解糖源作朋 (glycogenolysis)の昰盛

\begin{tabular}{c|c|c}
\multicolumn{3}{c}{ 第 1 麦 } \\
\hline 經過日數 & $\begin{array}{c}\text { 血 糖量 } \\
\mathrm{mg} / \mathrm{dl}\end{array}$ & $\begin{array}{c}\text { 尿總楉量 } \\
\mathrm{g}\end{array}$ \\
\hline 術 前 & 124 & $(-)$ \\
1 & 395 & 11.65 \\
2 & 383 & 15.33 \\
3 & 440 & 6.80 \\
4 & & 7.98 \\
& & 死 亡 \\
\hline
\end{tabular}

b. 非糖物質からの糖生成の旺盛

c. 胿外組織に於ける糖の喓化分解減弱

管の場合を擧げる事が出來る。

以上 3 項目中糖の酸化分解減弱による血糖への影響は䍄つ㨨取糖 質處理袎能上では要位を占むるものであるが，早朝時血糖位に對し ては其影響は少いものであると侾える，

そ弓すれば早朝時高血糖の原因的異常代謝としては，解糖原及び

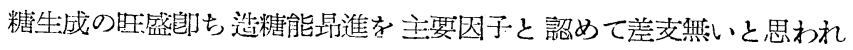
万.

其處で造糖能昆進度を妇價する目標として，早朝空腹時の血糖量 を選んだ譯である。少尿糖の全排出量は攝取糖質處理機能失調度に も關倸があり，文浩糖能昂進度つ方にも關倸があるものであるが， 便宜上本項目中へ插入にた。

（1）除膵犬に於ける早朝時血糖位並びに全尿糖量の經過

(a) 膵全剔犬に於ける早朝時血糖位並びに尿糖量經過

(b) 膵 17 / 8 部剔犬に於ける早朝時血糖位並びに或糖量經過 除膵術後 52 日間に至る閏の血糖，尿糖の經過は次表(第 2 表)に示 寸通りである。

除膵後 3 日で上鼠した血糖位は, 除膵後 12 日迄略々同高位を持續 したが, 術後 12 日以後再鼠, 其後死亡(随後52日) に至る迄の間, $300 \mathrm{mg} / \mathrm{dl}$ 队外の血糖位を持䋶しつつ, 其聞 2 回 $400 \mathrm{mg} / \mathrm{dl}$ に揬近す

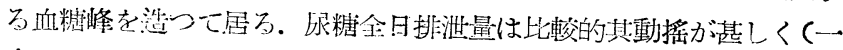

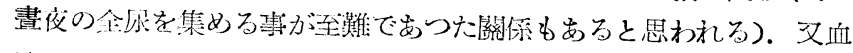

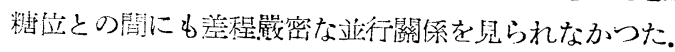

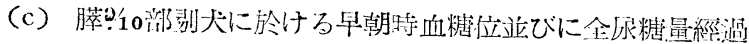

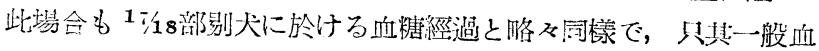

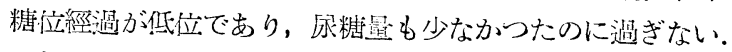

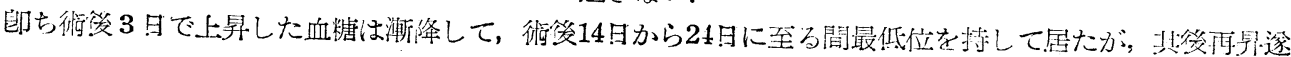
に惦後 57 日で死亡に至る迄 $200 \mathrm{mg} / \mathrm{dl}$ 以上の血糖位を持縝して挋る。

尿糖も略及血糖位に兹行して經遗して居る，

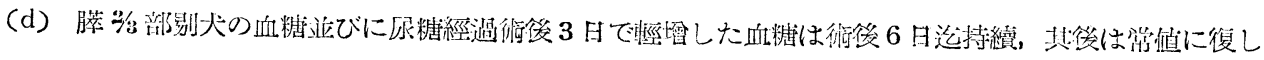
て居る。
第 2 表

䐆17/18部剔犬に於ける早 期血糖位並に尿糖量經過

\begin{tabular}{|c|c|c|}
\hline 經過日數 & $\begin{array}{l}\text { 血 糖 量 } \\
\mathrm{mg} / \mathrm{dl}\end{array}$ & $\begin{array}{c}\text { 尿總糖量 } \\
\mathrm{g}\end{array}$ \\
\hline 術 前 & 82 & $(-)$ \\
\hline 1 & 134 & 0.23 \\
\hline 2 & 168 & 1.03 \\
\hline 3 & 243 & 4.7 \\
\hline 5 & 248 & \\
\hline 7 & 241 & \\
\hline 10 & & 48.75 \\
\hline 11 & & 29.99 \\
\hline 12 & 297 & \\
\hline 13 & & 12.79 \\
\hline 14 & 415 & \\
\hline 16 & & 7.54 \\
\hline 18 & 305 & \\
\hline 19 & 275 & \\
\hline 21 & 281 & \\
\hline 24 & & 19.04 \\
\hline 25 & 385 & \\
\hline 26 & 325 & \\
\hline 27 & & 65.15 \\
\hline 23 & 265 & \\
\hline 30 & & 50.75 \\
\hline 31 & 298 & \\
\hline 32 & & 32.13 \\
\hline 33 & 305 & \\
\hline 35 & 297 & 67.69 \\
\hline 39 & & 47.99 \\
\hline 40 & 260 & \\
\hline 42 & & 27.78 \\
\hline 45 & 296 & \\
\hline 46 & & 36.30 \\
\hline 49 & 345 & \\
\hline 52 & 308 & \\
\hline 53 & & 11.87 \\
\hline 55 & & 死亡 \\
\hline
\end{tabular}


第 3 表

縢9/10部剔犬に於ける早

朝血糖位並に尿糖量經過

\begin{tabular}{|c|c|c|}
\hline 日數經過 & $\begin{array}{c}\text { 血 糖 量 } \\
\mathrm{mg} / \mathrm{dl}\end{array}$ & $\begin{array}{c}\text { 尿總糖量 } \\
\mathrm{g}\end{array}$ \\
\hline 術 前 & 95 & $(-)$ \\
\hline 1 & 125 & \\
\hline 2 & 164 & 0.4 \\
\hline 3 & 245 & \\
\hline 4 & & 13.74 \\
\hline 7 & 261 & \\
\hline 11 & & 77.03 \\
\hline 13 & 147 & \\
\hline 14 & & 26.08 \\
\hline 15 & 116 & \\
\hline 16 & & 15.07 \\
\hline 18 & 105 & \\
\hline 20 & & 12.48 \\
\hline 22 & 113 & \\
\hline 23 & 93 & \\
\hline 34 & & 37.51 \\
\hline 35 & 269 & \\
\hline 39 & 221 & 2.62 \\
\hline 41 & & 56.32 \\
\hline 42 & 210 & \\
\hline 52 & 455 & 112.27 \\
\hline 57 & & 死 亡 \\
\hline
\end{tabular}

第 4 表

滕 $2 / 3$ 部剔犬の早朝血

糖位主に尿糖量經過

\begin{tabular}{c|r|c}
\hline 經過日數 & $\begin{array}{c}\text { 血 糖 } \\
\mathrm{mg} / \mathrm{dl}\end{array}$ & $\begin{array}{c}\text { 尿總糖量 } \\
\mathrm{g}\end{array}$ \\
\hline 術 前 & 86 & $(-)$ \\
1 & 78 & $(-)$ \\
2 & 84 & $(-)$ \\
3 & 130 & $(-)$ \\
5 & & $(-)$ \\
6 & 126 & \\
7 & 94 & \\
11 & & $(-)$ \\
12 & 93 & \\
21 & 106 & $(-)$ \\
31 & 85 & $(-)$ \\
\hline
\end{tabular}

第 5 表 (甲列)

alloxan70mg 顀蓝糖尿犬つ

早朝血糖位並に尿糖量經過

\begin{tabular}{|c|c|c|}
\hline 經過日數 & $\begin{array}{c}\text { 血 粘 } \\
\mathrm{mg} / \mathrm{d} 1\end{array}$ & $\begin{array}{c}\text { 尿總糖量 } \\
\mathrm{g}\end{array}$ \\
\hline 術 前 & 122 & $(-)$ \\
\hline 1 & 117 & 23.08 \\
\hline 2 & & 64.20 \\
\hline 3 & 213 & \\
\hline
\end{tabular}

$265 \quad 103.0$

192

276

35.0

13

14

15

18

21

22

$2 \overline{5}$

2 อิ

29

34

\begin{tabular}{l|l|r}
34 & 190 & $\begin{array}{r}49.88 \\
\text { 生 存 }\end{array}$ \\
\hline
\end{tabular}

(2) alloxan 粉尿犬に於ける 早朝時血糖位立びに全尿糖 量經過

(a) alloxan70mg(賞 $\mathrm{kg}$ )

\section{俱萑糖尿犬の血糖立でに尿糖經過}

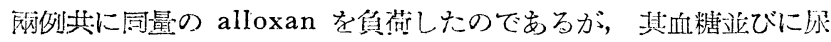

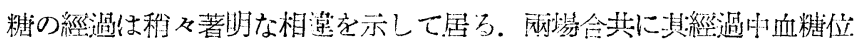
の動摇を見られるが，时例では一般に血糖位は低位で $200 \mathrm{mg} / \mathrm{dl}$ 间後

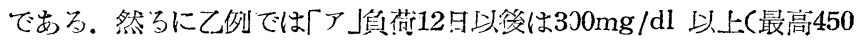

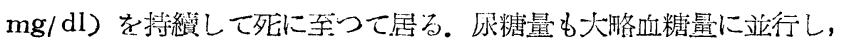
甲例では一般に少量であつたが，乙例では大量(47.7g)至112g)であ つた.

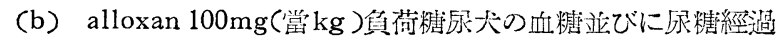

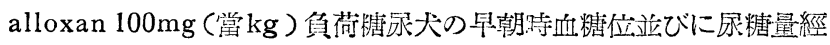
渦は，第11圖に示与通りであるが，其血糖量經過は「ア」70mg(當 $\mathrm{kg}$ ) 真荷乙例と略《相以で，「ア筫荷後 3 日で上杽した血糖は $250 \mathrm{mg} / \mathrm{dl}$

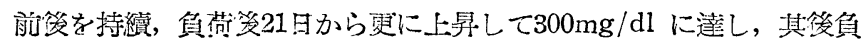

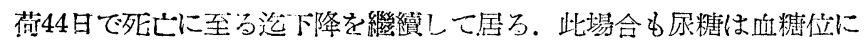
比して大量に排泄せられて居る。 
第 7 表

alloxan $100 \mathrm{mg}$ 賀街糖尿犬心於 ける早朝血糖位並に尿糖量經過。

\begin{tabular}{c|c|c}
\hline 經過日數 & $\begin{array}{c}\text { 血 桭 } \\
\mathrm{mg} / \mathrm{dl}\end{array}$ & $\begin{array}{c}\text { 永總糖量 } \\
\mathrm{g}\end{array}$ \\
\hline 術 前 & 88 & 0 \\
1 & 73 & 8.6 \\
2 & & 30.76 \\
3 & 305 & 44.61 \\
7 & 243 & 92.82 \\
12 & 257 & 119.0 \\
14 & 243 & \\
16 & & 110.24 \\
21 & 256 & \\
22 & & 76.07 \\
26 & 311 & \\
32 & & 86.52 \\
33 & 183 & \\
37 & 192 & \\
44 & & 死 亡 \\
\hline
\end{tabular}

以上除膵犬と alloxan 犬の血糖立びに尿糖經過を比輍するのに, 早 期持の血糖位經遗では，除膵と「ア」犬との間に特に認もべき相違を認 めないが，瓦糖に於ては网場合の間に著明な差遠を認められる。邲ち 一般に「ア」犬では其血糖位に比㙻して大量の㩆糖か排泄世られ，特に



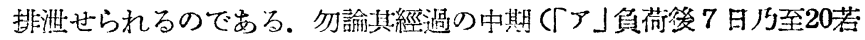
(は30日)に於ても其退糖排沺量は，除膵犬に比して高度である。份 「ア」犬では其死亡する場合, 其經過の末期に至ると急に尿糖も血糖も 減じて來るのに反して，膵部剔犬では症狀が惡化して死しに至る場合 は血糖は一蟹昇膫に向う。

霓するに浩糖能昆進と云う點では，膵全剔犬が最高度である事は明 であるが，部剔犬と「ア」犬とでは一般的には膵部剔犬の方が血糖位が 高く, 行も症狀が惡化して死亡に至る場合は, 膵部剔犬では血糖洴 騰に向い,「ア」犬では㴬降に向う。

尿糖排出は一般に「ア」犬の方が高度で，且つ「ア」䝿荷の初期から血 糖位に比して高度な水糖排出量を見られる。

\section{（III）「ケトン」血並びに「ケトン」尿の比較}

(1) 除膵犬に於ける「ケトン」血立びに「ケトン」胍

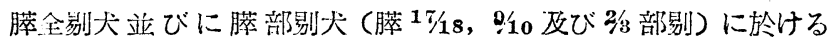
Ketosis の經過を第 8 表:示せボ火次通りである。

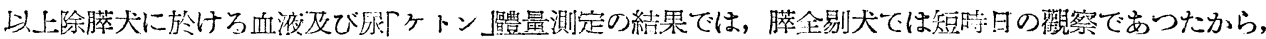
Ketosis の程摭を明碓にし得なからたが，長時日觀察の备膵部剔犬では，17/18 部剔犬以外は殆ど認むべき

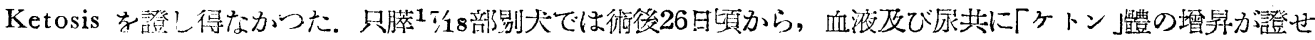

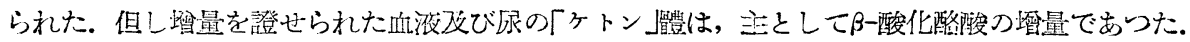

(2)「ア糖尿犬に於ける「ケトン」血兹びに「ヶトン」尿

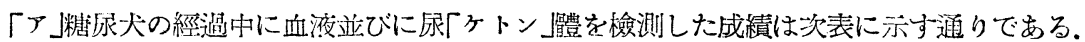

第 8 表（a）除䑅犬に於ける血液及び尿「ケトン體經過企

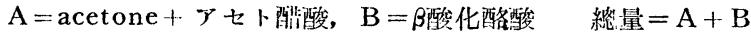

\begin{tabular}{|c|c|c|c|c|c|c|}
\hline \multirow[b]{3}{*}{$\begin{array}{l}\text { 手術後の } \\
\text { 經過日數 }\end{array}$} & \multicolumn{3}{|c|}{ 㨫: } & \multicolumn{3}{|c|}{ 剔 } \\
\hline & 血 & \multicolumn{2}{|c|}{ 液 $\mathrm{mg} \%$} & \multicolumn{3}{|c|}{ 尿 $\mathrm{mg}$} \\
\hline & A & B & 總 量 & A & B & 總 量 \\
\hline 術 & 0 & 0 & 0 & 0 & 0 & 0 \\
\hline 1 & 0 & 0 & 0 & 0 & 0 & 0 \\
\hline 2 & 1.2 & 0.15 & 1.35 & 0 & 2 & 2 \\
\hline 3 & 0 & 0.1 & 0.10 & 1 & 4 & 5 \\
\hline 4 & & & & 0 & 5 & 5 \\
\hline & & & & & & 死 亡 \\
\hline
\end{tabular}


第 8 表 (b) 除荟犬に於ける血液及び尿「アトン體經過表

$\mathrm{A}=$ acetone $++\boldsymbol{\Gamma}$ セ䤃酸， $\mathrm{B}=\beta$ 酸化酪酸總 量 $=\mathrm{A}+\mathrm{B}$

\begin{tabular}{|c|c|c|c|c|c|c|}
\hline \multirow[b]{3}{*}{$\begin{array}{l}\text { 手術後の } \\
\text { 經過日數 }\end{array}$} & & 搭 & $9 / 10$ & 部 & 剔 & \\
\hline & II & \multicolumn{2}{|c|}{ 液 $\mathrm{mg} \%$} & \multicolumn{3}{|c|}{ 尿 $\mathrm{mg}$} \\
\hline & A & B & 總 量 & A & B & 總 量 \\
\hline 街 前 & 0.05 & 0.1 & 0.15 & 0 & 1 & 1 \\
\hline 2 & 0.05 & 0.20 & 0.25 & 2 & 4 & 6 \\
\hline 7 & 0.05 & 0.10 & 0.15 & & & \\
\hline 11 & 0.05 & 0.10 & 0.15 & 0.5 & 3 & 3.5 \\
\hline 13 & 0 & 0.10 & 0.10 & 1 & 1 & 2 \\
\hline 23 & 0.05 & 0.05 & 0.10 & 0.05 & 3.0 & 3.5 \\
\hline 29 & 0.05 & 0.05 & 0.10 & & & \\
\hline 34 & 0.07 & 0.07 & 0.14 & 1.0 & 5.0 & 6.0 \\
\hline 39 & 0.02 & 0.02 & 0.04 & & & \\
\hline 41 & & & & 1 & 16 & 17 \\
\hline 42 & 0 & 0 & 0 & & & \\
\hline 52 & 0.05 & 0.20 & 0.25 & 2 & & \\
\hline & & & & & & 死亡 \\
\hline
\end{tabular}

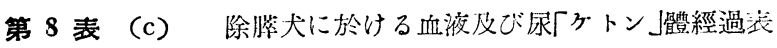

$\mathrm{A}=$ acetone $+ア セ$ アン陆酸, $\mathrm{B}=\beta$ 唒化酪酸 總量 $=\mathrm{A}+\mathrm{B}$

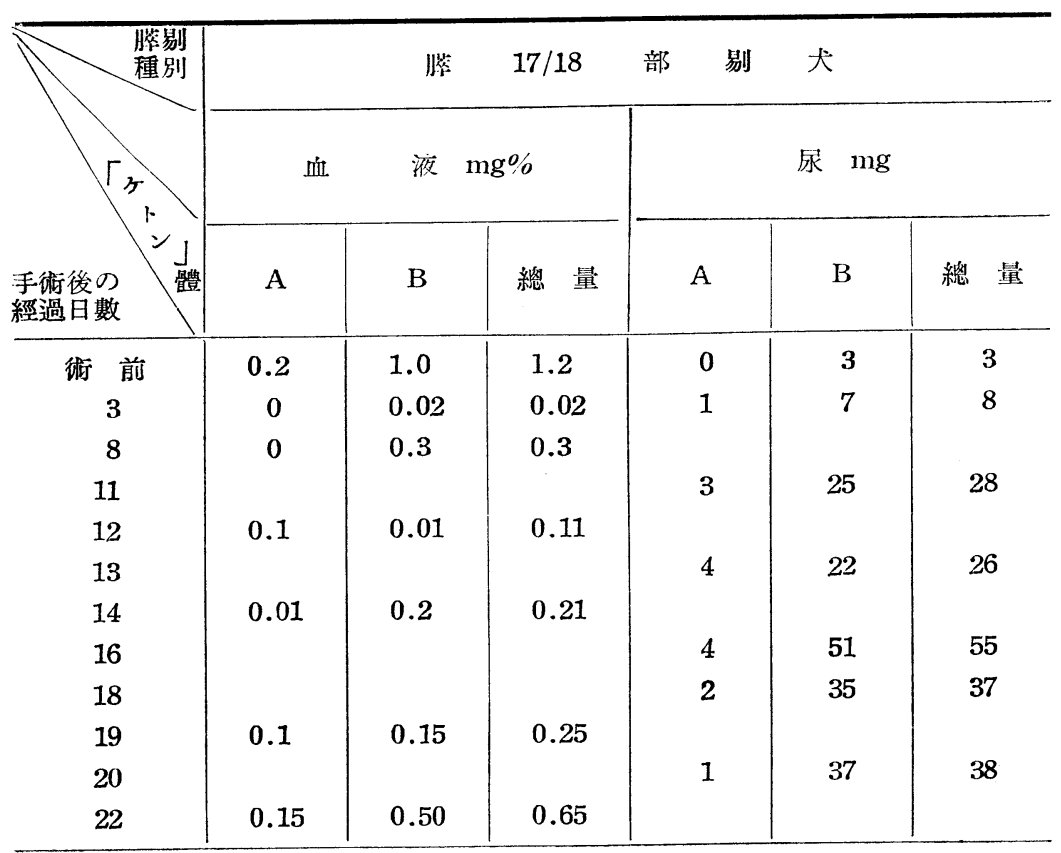




\begin{tabular}{|c|c|c|c|c|c|c|}
\hline 25 & & & & 3 & 5 & 8 \\
\hline 26 & 0.15 & 2.70 & 2.85 & & & \\
\hline 27 & & & & 35 & 140 & 175 \\
\hline 28 & 0.50 & 1.40 & 1.90 & & & \\
\hline 30 & 0.70 & 2.30 & 3.00 & & & \\
\hline 32 & & & & 20 & 85 & 105 \\
\hline 36 & 0.70 & 1.57 & 2.27 & & & \\
\hline 39 & & & & 4 & 104 & 108 \\
\hline 40 & 0.40 & 0.60 & 1.0 & & & \\
\hline 42 & & & & 3 & 55 & 58 \\
\hline 45 & 0.50 & 1.30 & 1.80 & & & \\
\hline 46 & & & & 1 & 40 & 41 \\
\hline 52 & 0.30 & 0.40 & 0.70 & & & \\
\hline 53 & & & & 0 & 15 & 15 \\
\hline 56 & & & & & & 死亡 \\
\hline
\end{tabular}

第 8 表 (d) 除櫒犬に於ける血液及び尿「ケトン」體經過表 $\mathrm{A}=$ acetone $+\boldsymbol{\Gamma}$ セ卜醋酸， $\mathrm{B}=\beta$ 酸化酪酸 $\quad$ 總量 $=\mathrm{A}+\mathrm{B}$

\begin{tabular}{|c|c|c|c|c|c|c|}
\hline \multirow[b]{3}{*}{$\begin{array}{l}\text { 手術後の } \\
\text { 經遭過數 }\end{array}$} & \multicolumn{2}{|r|}{ 搭 } & \multirow[t]{2}{*}{$2 / 3$} & 剔 & \multicolumn{2}{|l|}{ 犬 } \\
\hline & \multicolumn{2}{|c|}{ 液 $\mathrm{mg} \%$} & & \multicolumn{3}{|c|}{ 尿 $\mathrm{mg}$} \\
\hline & A & B & 總 量 & A & B & 總 量 \\
\hline 石 前 & 0 & 0 & 0 & 0 & 1 & 1 \\
\hline 3 & 0 & 0.05 & 0.05 & & & \\
\hline 5 & & & & 1 & 3 & 4 \\
\hline 10 & 0 & 0.02 & 0.02 & & & \\
\hline 11 & & & & 3 & 12 & 15 \\
\hline 14 & 0 & 0 & 0 & & & \\
\hline 21 & 0.1 & 0.02 & 0.12 & 0.5 & 3 & 3.5 \\
\hline
\end{tabular}

第 9 表（a）犬こ於ける血液及び尿「ケトン」體經過攱

$\mathrm{A}=$ acetone $+\gamma$ セ卜醋酸, $\mathrm{B}=\beta$ 酸化酪酸 總量 $=\mathrm{A}+\mathrm{B}$

\begin{tabular}{|c|c|c|c|c|c|c|c|}
\hline \multirow[b]{3}{*}{$\begin{array}{l}\text { 手術後の } \\
\text { 經過日數 }\end{array}$} & \multicolumn{7}{|c|}{$70 \mathrm{mg} / \mathrm{kg}$ 費荷アロキサン犬 } \\
\hline & \multirow[t]{2}{*}{ 血 } & \multicolumn{2}{|c|}{ 液 $\mathrm{mg} \%$} & \multicolumn{4}{|c|}{ 尿 $\mathrm{mg}$} \\
\hline & & $\mathrm{B}$ & 總 量 & A & B & 總 & 量 \\
\hline 術 前 & 0 & 0.15 & 0.15 & $\begin{array}{l}0 \\
0\end{array}$ & $\begin{array}{l}0 \\
0\end{array}$ & & $\begin{array}{l}0 \\
0\end{array}$ \\
\hline
\end{tabular}




\begin{tabular}{r|r|r|r|r|r|r}
\hline 2 & 0.35 & 0.85 & 1.20 & & & 0 \\
4 & & & & 0 & 0 \\
5 & 0.40 & 0.75 & 1.15 & & & \\
6 & & & & 2 & 5 & 7 \\
7 & 0.40 & 0.55 & 0.95 & 2 & 5 & 7 \\
9 & 0.40 & 0.55 & 0.95 & & & \\
12 & 0.45 & 0.85 & 1.30 & 10 & 25 & 35 \\
14 & 0.55 & 0.35 & 0.90 & 15 & 38 & 43 \\
16 & 1.15 & 0.95 & 2.10 & & & \\
19 & 0.45 & 0.45 & 0.90 & 54 & 68 & 122 \\
28 & 0.95 & 0.85 & 1.80 & 22 & 51 & 73 \\
30 & 1.00 & 0.90 & 1.90 & 20 & 75 & 95 \\
33 & & & & 32 & 130 & 152 \\
35 & 0.70 & 0.30 & 1.00 & & & 33 \\
40 & & & & 2 & 31 & 32 \\
42 & 2.50 & 2.20 & 4.70 & & & \\
45 & 0.55 & 0.70 & 1.25 & 9 & 63 & \\
死 & & & & & & \\
\hline
\end{tabular}

第 9 表（b） alloxan 犬に於ける血液及び尿「ケトン」體經過表

$\mathrm{A}=$ acetone $++\boldsymbol{Y}$ セ卜醋酸, $\mathrm{B}=\beta$ 酸化酪酸 $\quad$ 總量 $=\mathrm{A}+\mathrm{B}$

\begin{tabular}{|c|c|c|c|c|c|c|c|}
\hline \multirow[b]{3}{*}{$\begin{array}{l}\text { 手術後の } \\
\text { 渔過日數 }\end{array}$} & \multicolumn{7}{|c|}{$100 \mathrm{mg} / \mathrm{kg}$} \\
\hline & \multicolumn{3}{|c|}{ 液 $\mathrm{mg} \%$} & \multicolumn{4}{|c|}{ 尿 $\mathrm{mg}$} \\
\hline & A & B & 總 量 & A & B & 總 & 量 \\
\hline 術 前 & 0.15 & 0.10 & 0.25 & 0 & 0 & & 0 \\
\hline 1 & 0.05 & 0 & 0.05 & & & & \\
\hline 2 & & & & 0 & 0 & & 0 \\
\hline 3 & $\mathbf{0}$ & 0.01 & 0.01 & & & & \\
\hline 7 & 0 & 0.10 & 0.10 & 2 & 5 & & 7 \\
\hline 12 & 0 & 0 & 0 & & & & \\
\hline 15 & & & & 12 & 19 & & 31 \\
\hline 16 & 0.15 & 0.30 & 0.45 & & & & \\
\hline 21 & 0 & 0.05 & 0.05 & & & & \\
\hline 31 & & & & 1 & 18 & & 19 \\
\hline 39 & 0 & 0 & 0 & 0 & 9 & & 9 \\
\hline 死亡 & & & & & & & \\
\hline
\end{tabular}

以上「ア」犬に於ける血液及び尿「ヶトン體量を其經過に從つて檢測した成績では，「ア」70mg 負荷糖尿犬 に於て特に其末期に著明な Ketosis を證せられ，他の100mg負荷の場合には輕度の Ketosis を證せられた のに過ぎなからた。

以上除萃犬と「ア」犬の血液及び尿「ヶトン」體量を比輘した結果では, 兩場合共に Ketosis の高度は, 
其各場合によつて䅌及著明な相違があつて，精礁な比輍は困蜼である。网場合共に各 1 例に於て稍々高度な

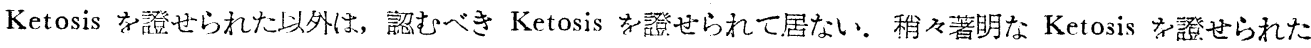

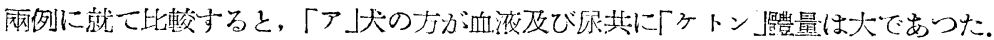

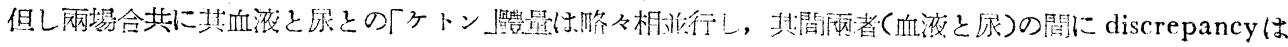
認められなからた。

（IV）除膵犬と「ア」犬に於ける血糖の對 Insulin 感性に關する比較

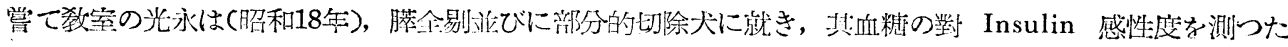

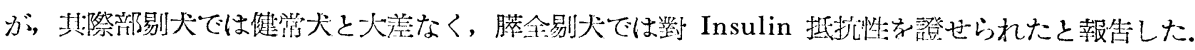

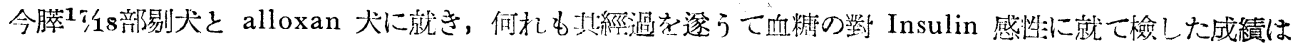
次表(第3表及び第 4 表)に示与樋りである。

alloxan 糖尿犬の對 Insulin 血糖反㗹經過

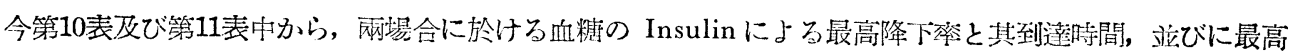

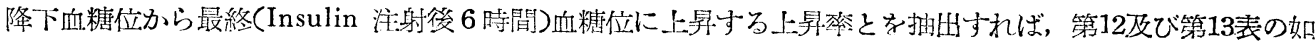
くである。

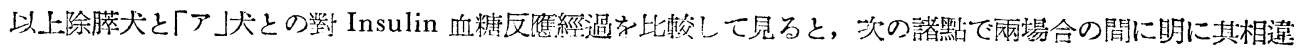
为澄明せられる。

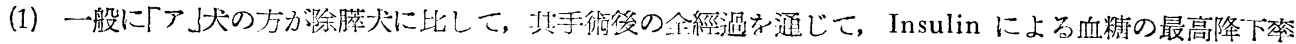
(感性度)が高度である。

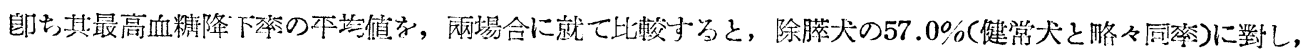

第 10 表 鋚17/18 部剔犬血糖の對 Insulin 感性度經過

\begin{tabular}{|c|c|c|c|c|c|c|c|c|}
\hline \multirow{2}{*}{\multicolumn{2}{|c|}{$\begin{array}{l}\text { 「イ丁泩射 } \\
\text { 後の時闔 } \\
\text { 術後 } \\
\text { 經過日數 }\end{array}$}} & \multicolumn{3}{|c|}{ 血 } & 量 & \multicolumn{2}{|c|}{$\mathrm{mg} / \mathrm{dl}$} & \multirow[b]{2}{*}{6} \\
\hline & & 注射前 & 1 & 2 & 3 & 4 & 5 & \\
\hline 術 & 前 & 82 & 38 & 40 & 35 & 40 & 55 & 72 \\
\hline 術行 & 日 & 250 & 103 & 90 & 90 & 92 & 105 & 125 \\
\hline 7 & 日 & 250 & 88 & 64 & 68 & 80 & 86 & 90 \\
\hline 14 & 日 & 415 & 224 & 175 & 182 & 224 & 196 & 230 \\
\hline 21 & 日 & 285 & 121 & 100 & 104 & 115 & 155 & 205 \\
\hline 28 & 日 & 265 & 207 & 188 & 223 & 270 & 293 & 305 \\
\hline 40 & 日 & 250 & 225 & 175 & 104 & 133 & 133 & 145 \\
\hline 45 & 日 & 295 & 235 & 175 & 145 & 128 & 115 & 126 \\
\hline 52 & 日 & 304 & 290 & 256 & 205 & 153 & 135 & 123 \\
\hline
\end{tabular}

第 11 表 alloxan 犬血糖の對 Insulin 感性度經過

\begin{tabular}{|c|c|c|c|c|c|c|c|c|}
\hline \multirow{2}{*}{\multicolumn{2}{|c|}{ 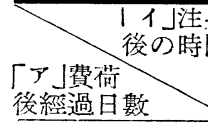 }} & \multicolumn{3}{|c|}{ 血. } & & \multicolumn{2}{|c|}{$\mathrm{mg} / \mathrm{dl}$} & \multirow[b]{2}{*}{6} \\
\hline & & 注射前 & 1 & 2 & $\varepsilon$ & 4 & 5 & \\
\hline \multirow{2}{*}{\multicolumn{2}{|c|}{$\begin{array}{l}\Gamma Y \text { 員荷前 } \\
\text { 負菏後 } 3 \text { 日 }\end{array}$}} & 103 & 65 & 43 & 54 & 60 & 81 & 92 \\
\hline & & 214 & 65 & 48 & 57 & 73 & 95 & 112 \\
\hline 7 & 日 & 190 & 80 & 52 & 46 & 75 & 80 & 96 \\
\hline 14 & 日 & 257 & 66 & 52 & 80 & 85 & 93 & 115 \\
\hline 21 & 日 & 220 & 61 & 68 & 67 & 93 & 114 & 125 \\
\hline 29 & 日 & 285 & 53 & 45 & 46 & 65 & 85 & 102 \\
\hline
\end{tabular}


第 12 表除荟犬に於ける「イ」泩射による血糖最高降下率(insulineffect)々其到達 時間並に最低血糖位上り最終血糖位への上昇率 (antiinsulineffect)

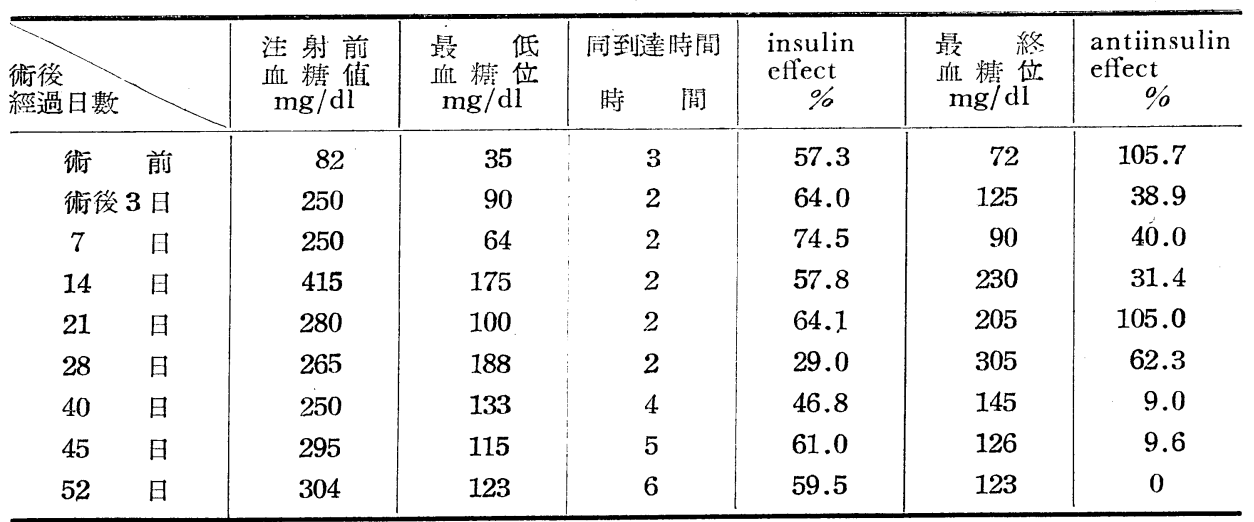

第 13 表 alloxan 犬に於ける「イ」注射による血糖最高降下樂(insulin effect) と 其到達時間並に最低血糖位上り最終血糖位への上昇率(antiinsulineffect)

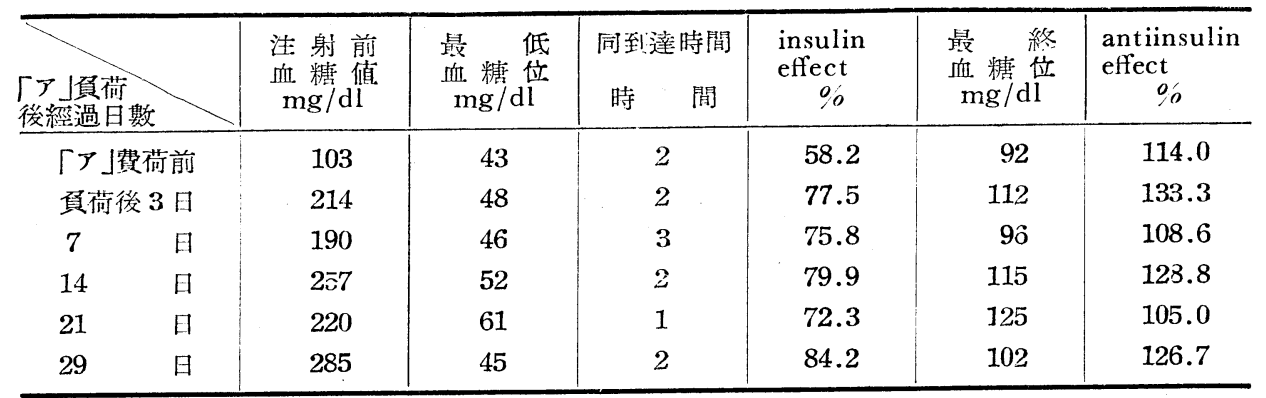

「ア」犬では77.9\%で其間著明な差違を證せられた。

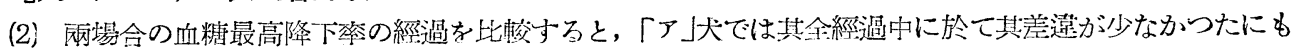

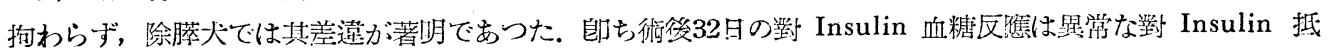
抗性を示し, 其血糖量最高降下薪は(Insulin 注射後 2 時聞) $29.6 \%$ であつて, 其最高降下䃋が極めて小であ つた以外に, Insulin 注射後 2 時間以後の血糖が，他の手泪日數に於ける場合とは相異して異掌な上昇を示 し, Insulin 注射後 6 時閒の終末血糖值は，注射解值よりも15\%の高值を示した。

(3) 次に爾場合に於ける Insulin 注射爱の最低血糖位(Insulinによる最高降下血糖位)加ら, 終末血糖位 への上昇率を比輍したのに，兩場合の間に顎著な相遠が澄せられた。

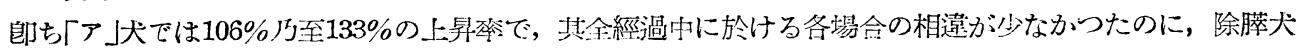
では手政後の經過日數によつて其間に著差が認められた。

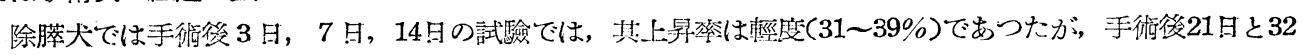
日の試驗に於て著霓し健常犬と胳々同率(105〜 115\%)となり，其後の試驗では著減し，最終試驗（手術後52 日)に於ては, Insulin 注射後 6 時間が最低血糖位を示すと云う思常な經過を見られた。

總括すると,「ア」犬では其 Insulin に對与る態度は其最高血糖降下紊に於ても, 其到達時間に於ても, 亦 Insulin 注射後の最低血糖位から終末血糖位への上昇卒に於ても, 其全經過目數を通じて殆ど不變であるの に拘わらず，除膵犬では種々の特畋な點が全經過中に認められた。

今 Insulin 注射後最低血糖位に達する迄の血糖降下作用を Insulineffect とし, 最低血糖位から上舁曲 線に暧ずる作用を antiinsulinffect とすれば， insulineffect は「ア」犬の方が除膵犬よりも稍々著明に大で 


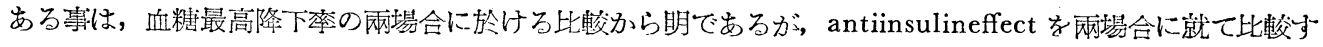

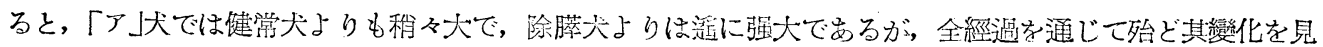

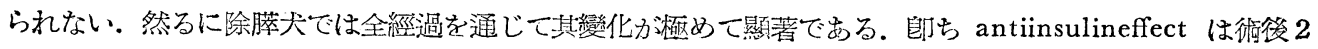

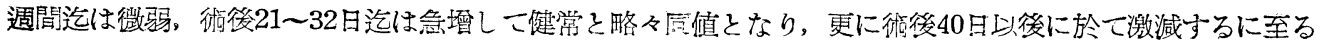
のである.

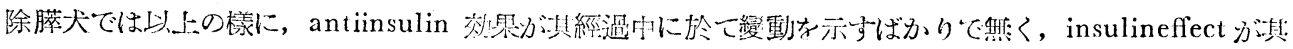

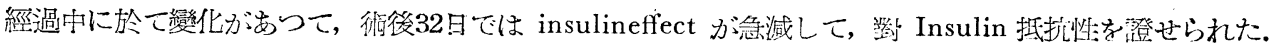

何故に除膵犬では，其經過中に於て，antiinsulin 及び insulneffect に變化を見られるのであるが，これ

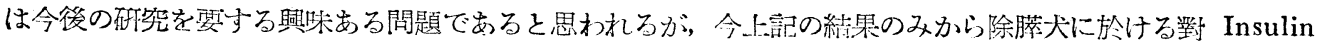
の特異な態度に就て，其理由を考察して見よう。

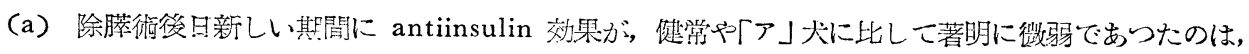
恐らく除膵による $\alpha$ 細胞の急激な機能閉仩による影響では䁫いかと推せられる.

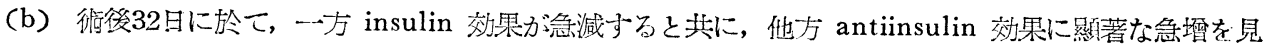

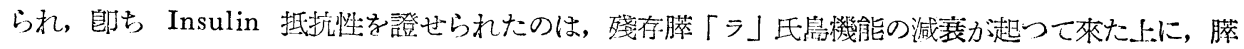
外性 antiinsulin 効果の增大が加わらた結果に因ると考えられる.

（c）很後40日以後に於て, insulineffect には變化を見られなからたか, antiinsulineffect に著减を見 殆ど antiinsulin 作用效果が證明出來ない程になつたのは，一旦旺盛となつた膵外性抗「イ」作用効

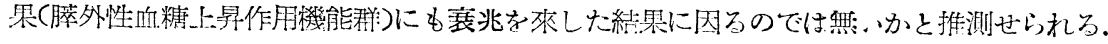

\section{第 4 章 要 約}

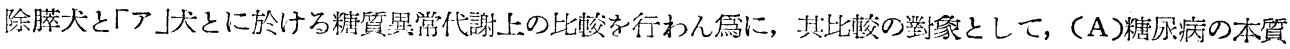
的代謝失調と (B) 萃外性病因の有㷛とを選び，前者の代表的要目として，1。攝取糖買處理機能 2 ，造糖

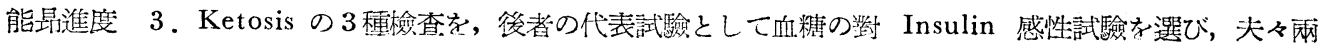
種糖尿犬に就て比輍を行い, 次の結果を得た。

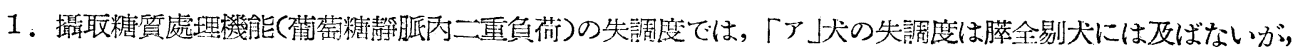

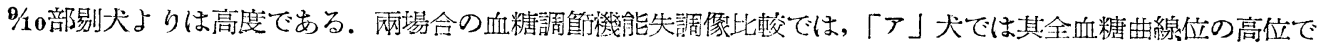
ある割合に, Stanb 効果の陰性度が著明で無い。

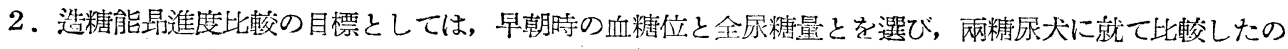
に，一般に「ア」犬では，膵全剔犬と比輍しては勿諭，膵部剔犬と比輍しても其血糖位の經過は低位で，而も 症狀が恶化して死に至る場合，除膵犬では血糖は昇鷯に向うのに反し，「ア」犬では漸降に向う。

侗特䔬なのは尿糖量であつて，尿糖排出は「ア」負荷の初期から血糖位に比して「ア」犬の方が著明に高度で， 而も「ア」大では「ア」真荇の初期から血糖位に比して高度な尿糖量の排泄が見られる。

3. Ketosis の比輍を兩場合に就て行つたのに, 兩場合共に其 Ketosis の高度は各場合によつて比輍的



4. 除膵犬と「ア」犬血糖の對 Insulin 感性と云う點に就て, 兩場合共に其經過を逐うて觀察比較した結 果、次の諸點に於て兩者の間に著差のあるのを知られた。

（a「「」犬の方が除膵犬よりも對 Insulin 感性は稍々著明に高度であつて, 其最高血糖降下率の本均

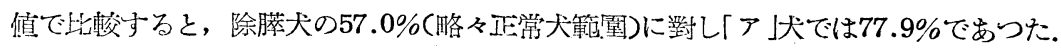

(b)「ア」犬では Insulin に對する態度は其最高血糖降下筫(insulineffect)に於ても, 其到達時間に於

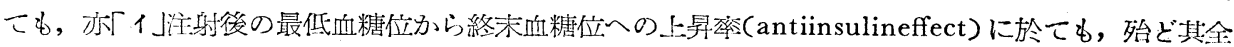

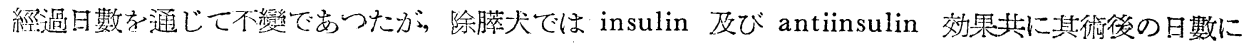
よつて著差を證せられた。

（c）除膵犬では術後 3 週間迄は antiinsulin 効果が徽弱, 術後 30 日前後で insulin 及び antiinsulin 
効果共に急增して insulin 抵抗性を證せられ，末期には antiinsulin 効果か激減する。

（d）以上の除膵犬に於ける術後經過によつて，insulin 及び antiinsulin 効果に疑著な變化を見られ

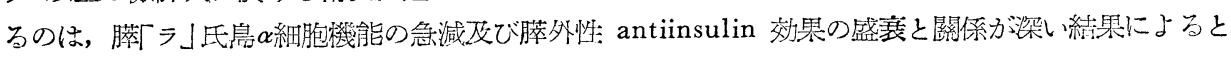
推せられる。

5 要するに除膵犬と「ア」犬とに於ける糖質代謝上の比較では, 其糖尿病の本質的代謝失調と云う點では,

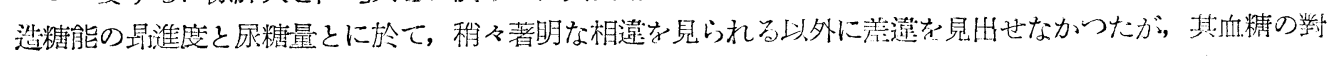

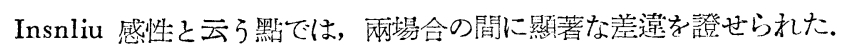

\section{文献}

1) Von Mering, J., and Minkowski, O.: Arch. f. exper. Path. u. Pharmakol., 23: 371, 1889-1890. 2) Allan, Bowie, Mecleod a. Robinson: Brit. J. Exp. Path., 5, 75, $1924 . \quad$ 3) Bailey C.C. a. Bailey : J. Am. Med. Ass., 122, 1165, $1943 . \quad$ 4) Goldner, M.G. a. Gomori, G.: Endocrinology, 33, 293, 1943. 5) Duff, G.L., : J. Med. Sci., 210, 381, $1945 . \quad$ 6) Ishii, T., : J. Biochem., 38, 37, 1951. 7) 長濱: 日本內分泌學誌, $28,279,1952 . \quad 8)$ 魚地: 日本藥理學誌，46, 86, 1950. 9) Kirschbaum, A., Wells, J.T., a. Molander D.: Proc. Soc. Exptl. Biol. Med., 58, 267, 1945. 10）小坂: 東京鿀事新誌, 59, 267, 1952. 11 ) Houssay, B.A.: Cand. Med. Assoc., 56, 517, 1949. 12) Thorogood, E., and Zimmermann, B., : Endocrinol., 37, 191, $1945 . \quad$ 13) Bailey, C.C. and Bailey, O.T., : J. Am. Med. Ass., 122, 1165, $1943 . \quad$ 14) Hughes, H., Ware, L.L., and Young, F. G.: Lancet, 246, 148, $1944 . \quad$ 15) Panerjee, S., : J. Biol. Chem., 158, 547, $1945 . \quad$ 16) Dunn, J. S., Sheehan, H. L., and McLetchie, N. G. B., : Lancet, 244, 484, $1943 . \quad$ 17) 岡本: 京都大學 紀要, 27, 43, 1949. 18 ) Kirschbaum, A., Welle, L.J. and Molander, D.: Proc. Soc. exp. Biol. and Med. 53, 294, $1945 . \quad$ 19) Houssay, B.A., Orias, O. and' Sara, J. G.: Science 101, 468, 1945. 20) Allen, F.M.: J. Exp. Med., 31, 363, 1920. 21) Bahre: J. Biol. Chem., 136, 25, 1940. 22) 光永: 東北筑學誌, $33,396,1943$. 